\title{
月二十年八十二治 明
}

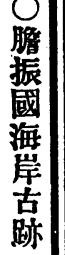

甚目索 閑 余

人堅 层 客

二 類 監 乘

竪 7 及

$ナ$ 七室中

貝蘭旬

報塚、思

道等有》

大 7 珠士

貴 探 云在

型見谠月 柇

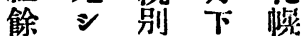

白多等 旬

二少郡、高

揭得芮テ

载ル海 室 畑

七 所 岸 蘭

ラ

$\checkmark v$ 古 $=$

广左跡寄 一

バ $=7$ 寓

幸數 搜 中

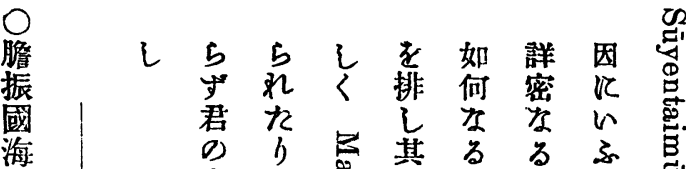

名此密 其 人調宜空

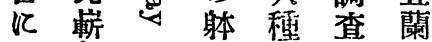

よ新圽名を地

b有宫上る 遂方

本力加列的

誌なの於《於式

上る一てつれ机出

に二ブ其きれる

表大ラの 區 り 熟迥.

白文ン言々 洏蕃

世字千䃁决乙梁

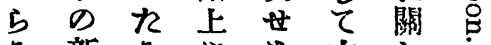

る新る化古と

光を於 b來て

なは證てし篡は

る 遠 明 正整 蕃 君

へ加せさ雲勾は

蓋個全”七個入川ト分全卜使存破四室

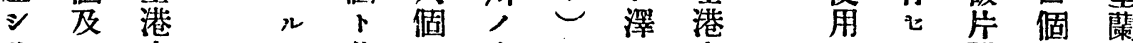
此七学 モ 共 $ア$ 左,, 字 等士 若

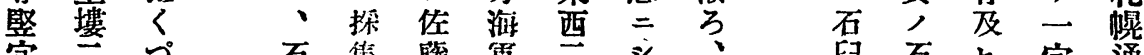

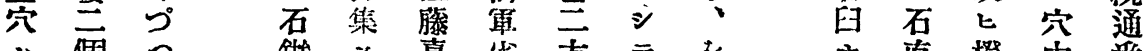
$\therefore$ 個つ鐫 志 $>$ 高鐵開右石八疱は徑

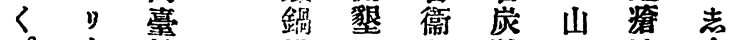

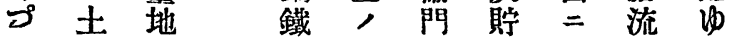

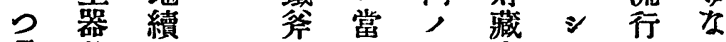

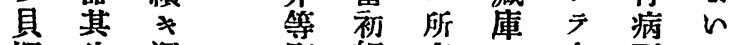
榐 他 澤 分思察長云東央, 应 㹂細有分中死

九 $\begin{array}{lll}\text { 几 } & \text { 物 } & \text { 太 } \\ \text { 凡 } & \text { 郎 }\end{array}$

九 元認 畑

町么 地

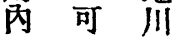

外 $\neq$ 䋒

, ₹ =

所, 朢

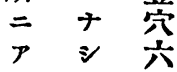

附ナ係堂二邓方

㘳士密條㢕、

於石器山村を

テ數 破腹細二は

场士片傾流蹛考

出個多 斜 海 $三$ 他

七 一

门塊石 三 三 名所

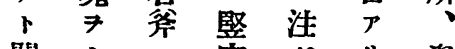

$\because$ 凡 橫 $\quad$ 地

全八谟》具

人 九

宅 寸截多長 地按断》藏 地 ス 部散 所 均ル $\Rightarrow$ 在有 二 = 第 飞 畑 折食 千 D , 石筩 $\mathrm{n}$ 附山 金品形近腹 二 7 狀 地 傾 個 破, 二 斜 ～碎 石 於 地 得 ス 刃n 個士 㹂 y = 現 器 宗 


\begin{tabular}{|c|c|c|c|c|c|c|c|c|c|c|c|c|c|c|c|c|c|}
\hline 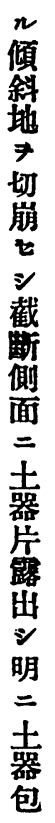 & 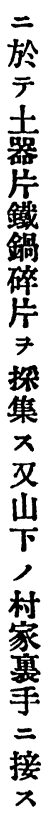 & 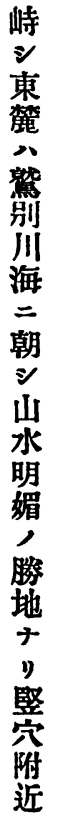 & 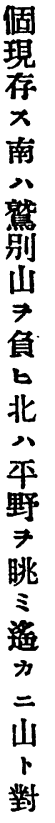 & 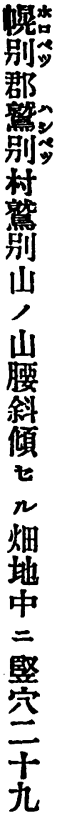 & 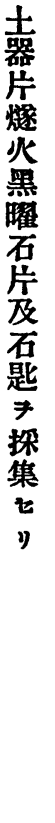 & 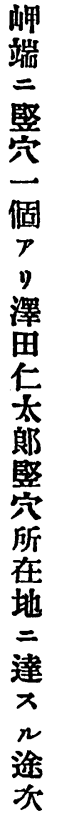 & 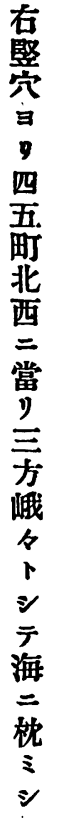 & $\begin{array}{l}\text { 器 } \\
\text { 䧺 } \\
\text { 在 } \\
\text { 丈 }\end{array}$ & 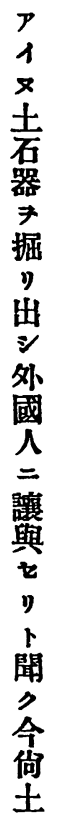 & 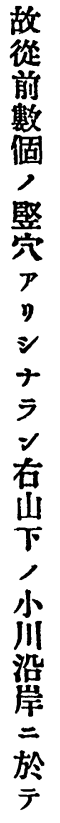 & 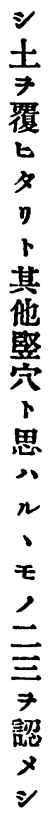 & 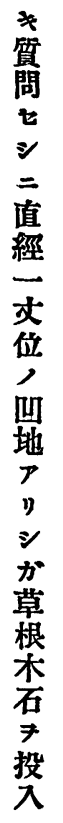 & 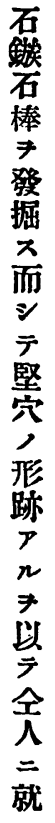 & 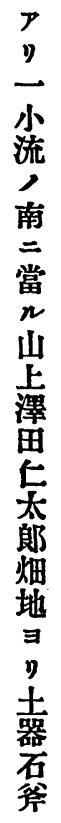 & 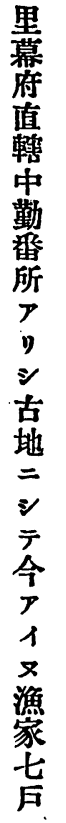 & 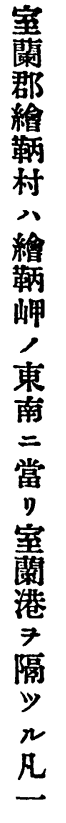 & y. \\
\hline $\begin{array}{l}\text { 㞇 } \\
\text { 跡 } \\
\text { 義 } \\
\text { ナ } \\
\text { y }\end{array}$ & 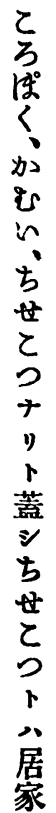 & 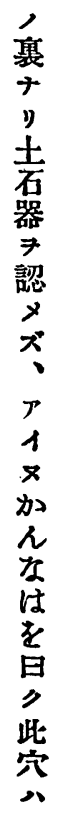 & 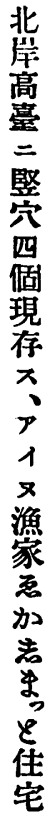 & 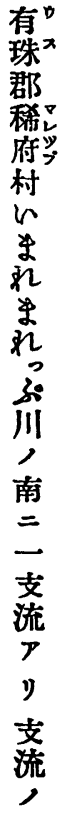 & $\begin{array}{c}\text { ᄏ } \\
\mathfrak{y} \\
\text { 掘 } \\
\text { 集 } \\
\text { y } \\
\text { 保 } \\
\text { 存 } \\
\text { 七 } \\
\text { y }\end{array}$ & 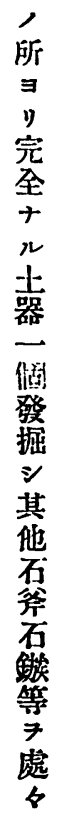 & 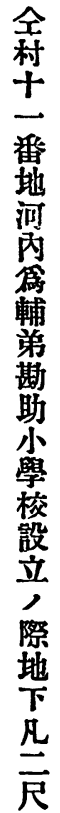 & 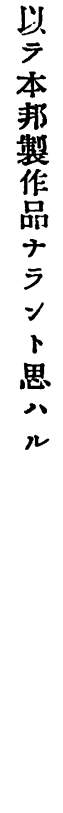 & 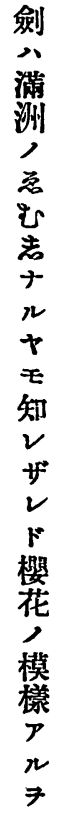 & 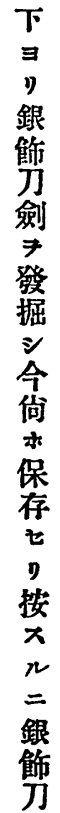 & 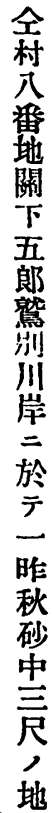 & 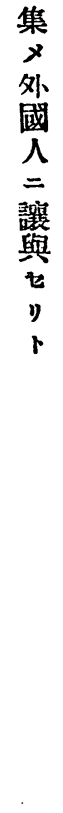 & 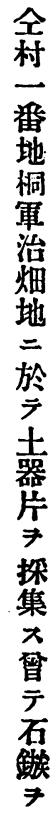 & $\begin{array}{c}\text { 具 } \\
\text { 毁 } \\
\text { 獸 } \\
\text { 骨 } \\
\text { 輕 } \\
\text { 石 } \\
\text { 等 } \\
\text { 散 } \\
\text { 在 } \\
\text { 七 } \\
\text { ๖ }\end{array}$ & 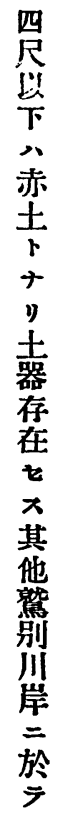 & 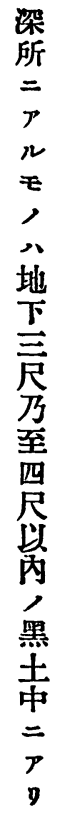 & 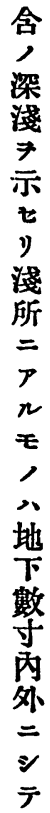 \\
\hline
\end{tabular}




\section{月二十年八十二治明}

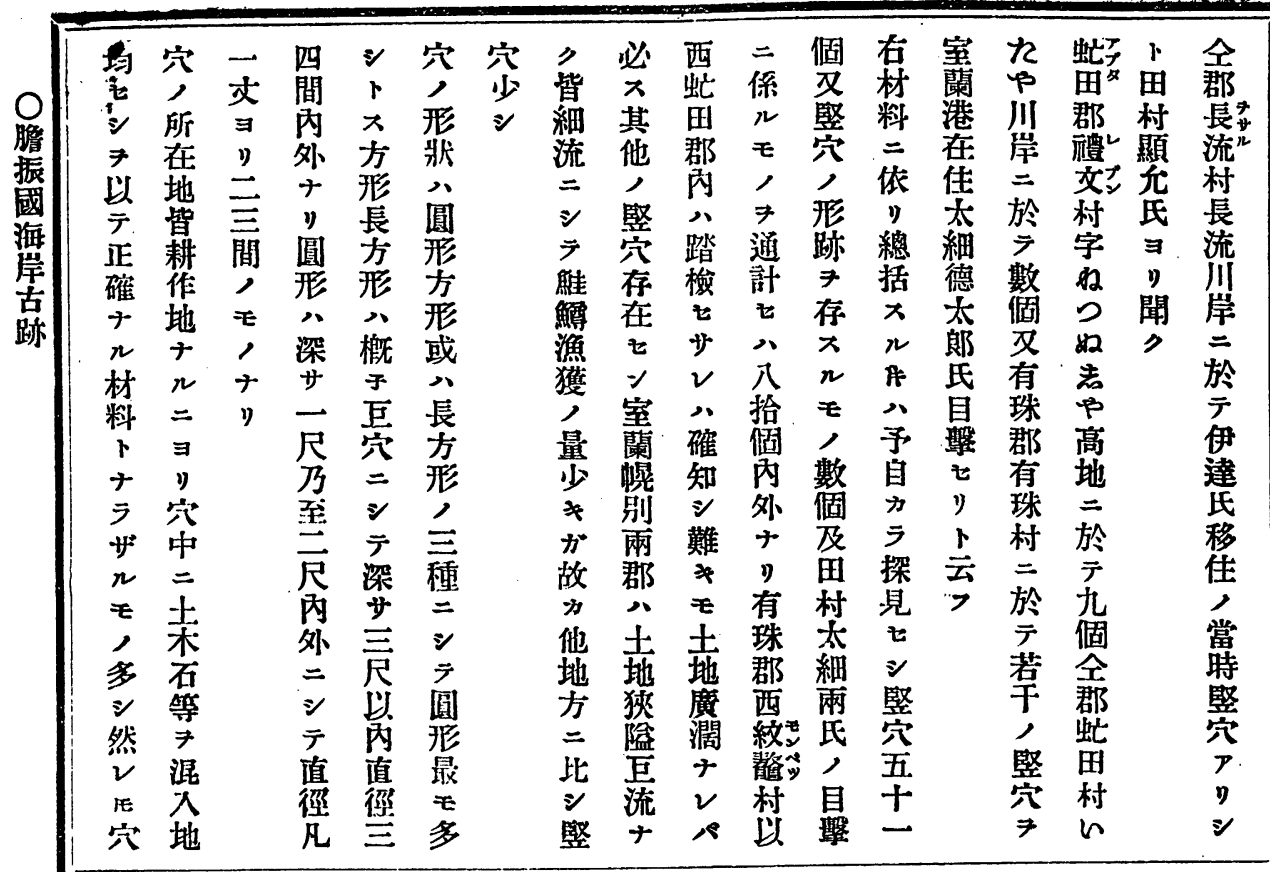

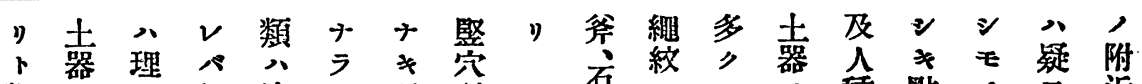

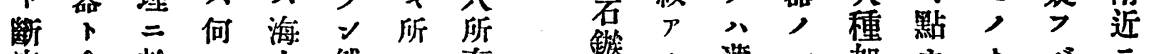

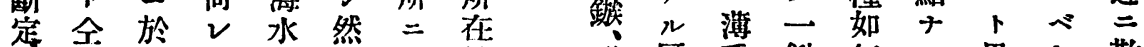

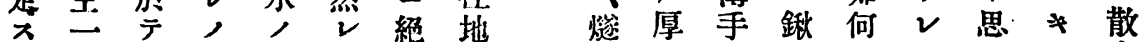
トナ然海温比示手ナ年,

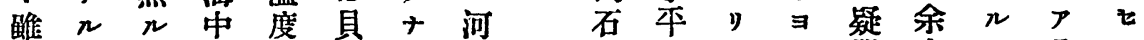

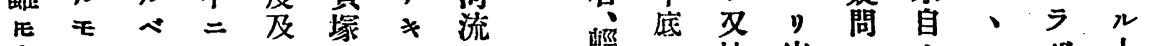

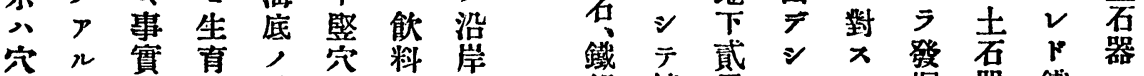

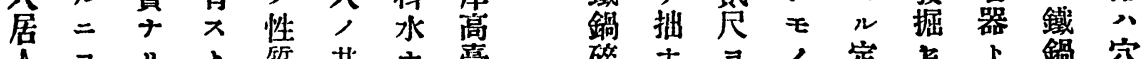

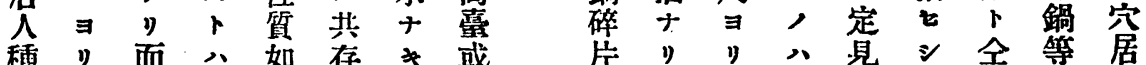

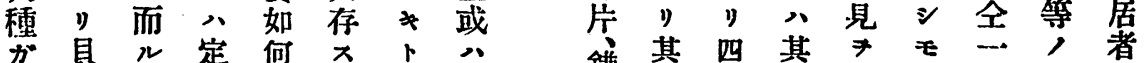
悉琭 $=\nabla=n$ 漁山鎆他尺製得, 個鐵保

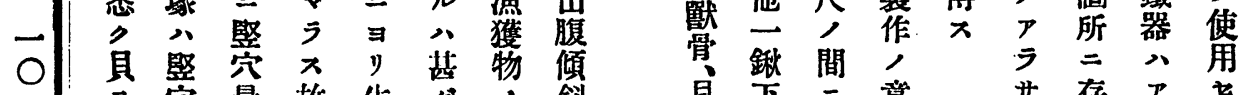

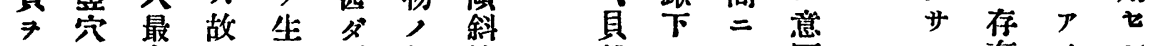
食人寄二青稀便地

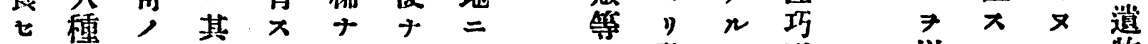

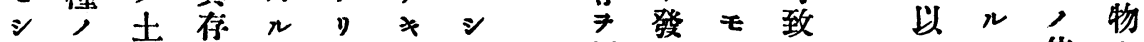

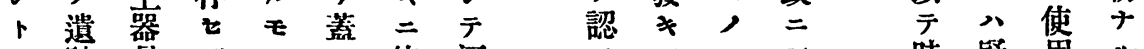

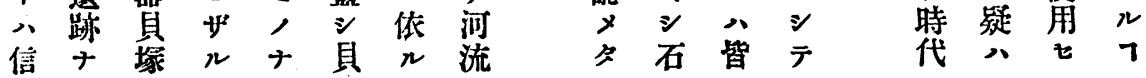


號七拾百第㱗雑會學類人京東

\begin{tabular}{|c|c|c|c|c|c|c|c|c|c|c|c|c|c|c|c|c|c|}
\hline 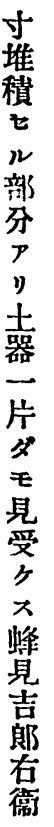 & 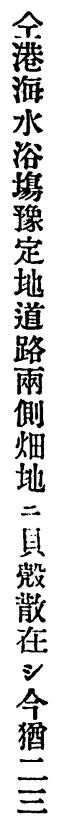 & 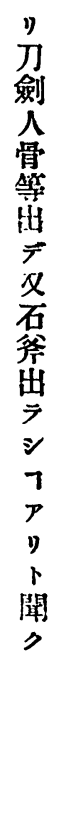 & 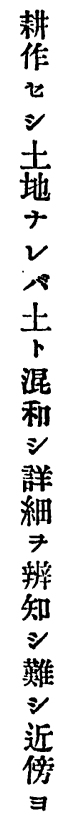 & 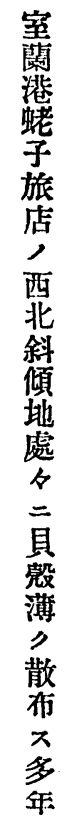 & $\begin{array}{c}\text { 認 } \\
x \\
\not \\
y\end{array}$ & 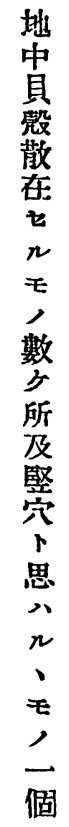 & 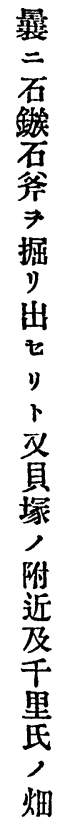 & 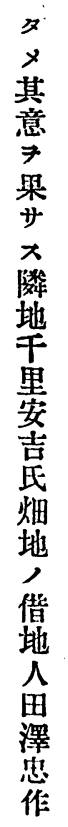 & 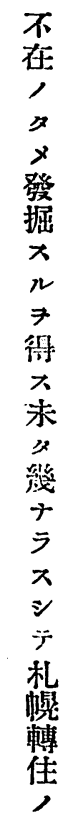 & 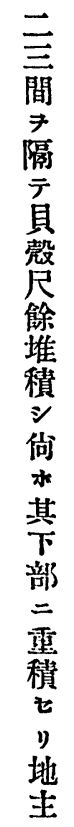 & 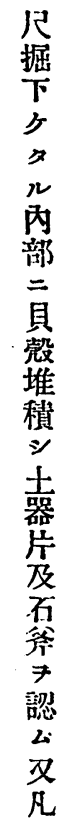 & 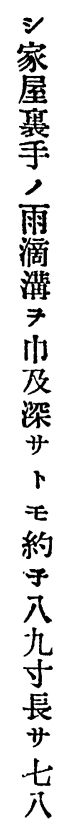 & 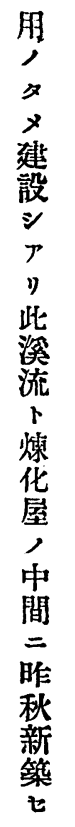 & 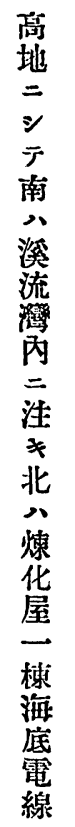 & 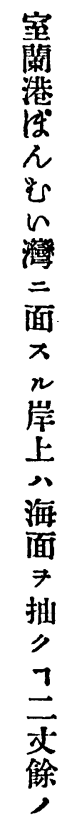 & $\underset{\text { 頁 }}{\stackrel{(}{\Xi}}$ & 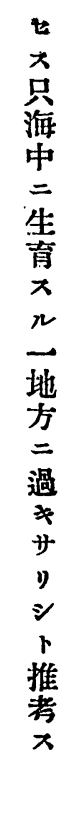 \\
\hline 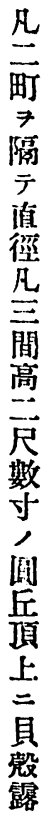 & 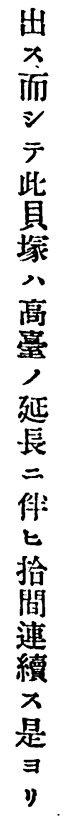 & 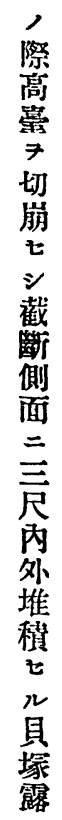 & 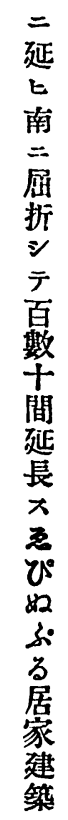 & 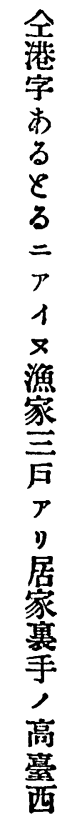 & 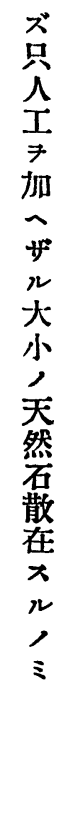 & 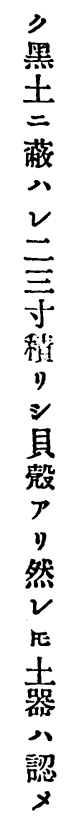 & 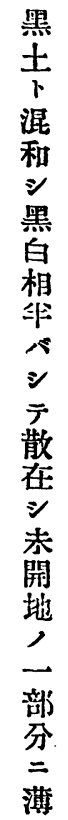 & 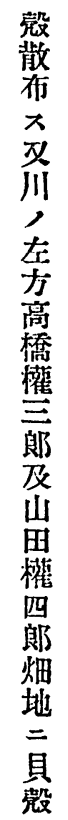 & 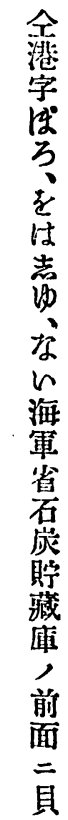 & 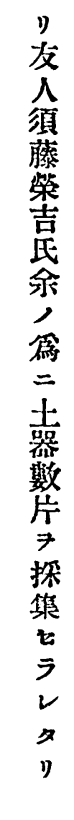 & 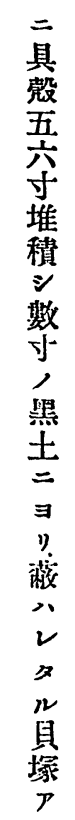 & 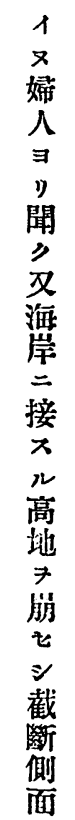 & 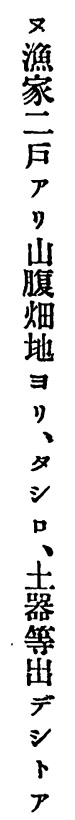 & 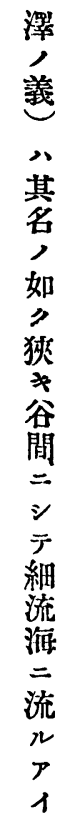 & 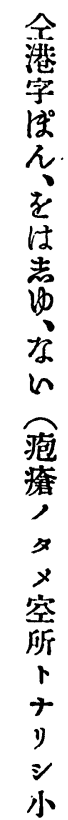 & $\begin{array}{c}\text { 掘 } \\
\text { 七 } \\
\text { y } \\
\text { 鍋 } \\
\text { 碎 } \\
\text { 告 } \\
\text { 個 } \\
\text { 畑 } \\
\text { 地 } \\
= \\
\text { 現 } \\
\text { 存 } \\
\text { y }\end{array}$ & 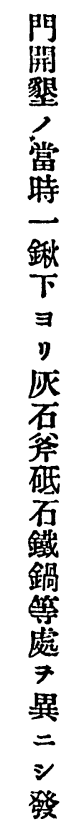 \\
\hline
\end{tabular}




\section{月二十年 $八+$ 二治明}

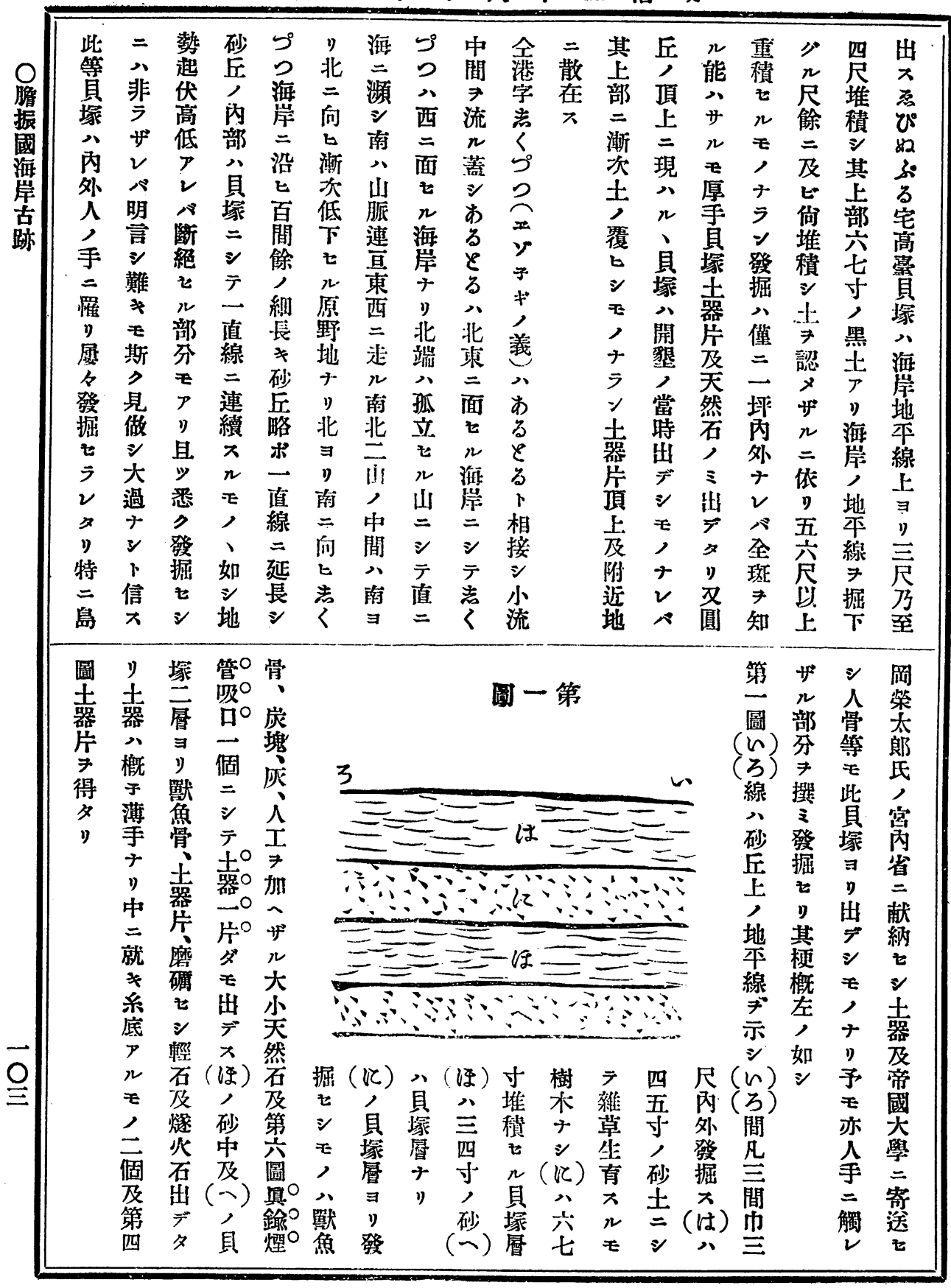




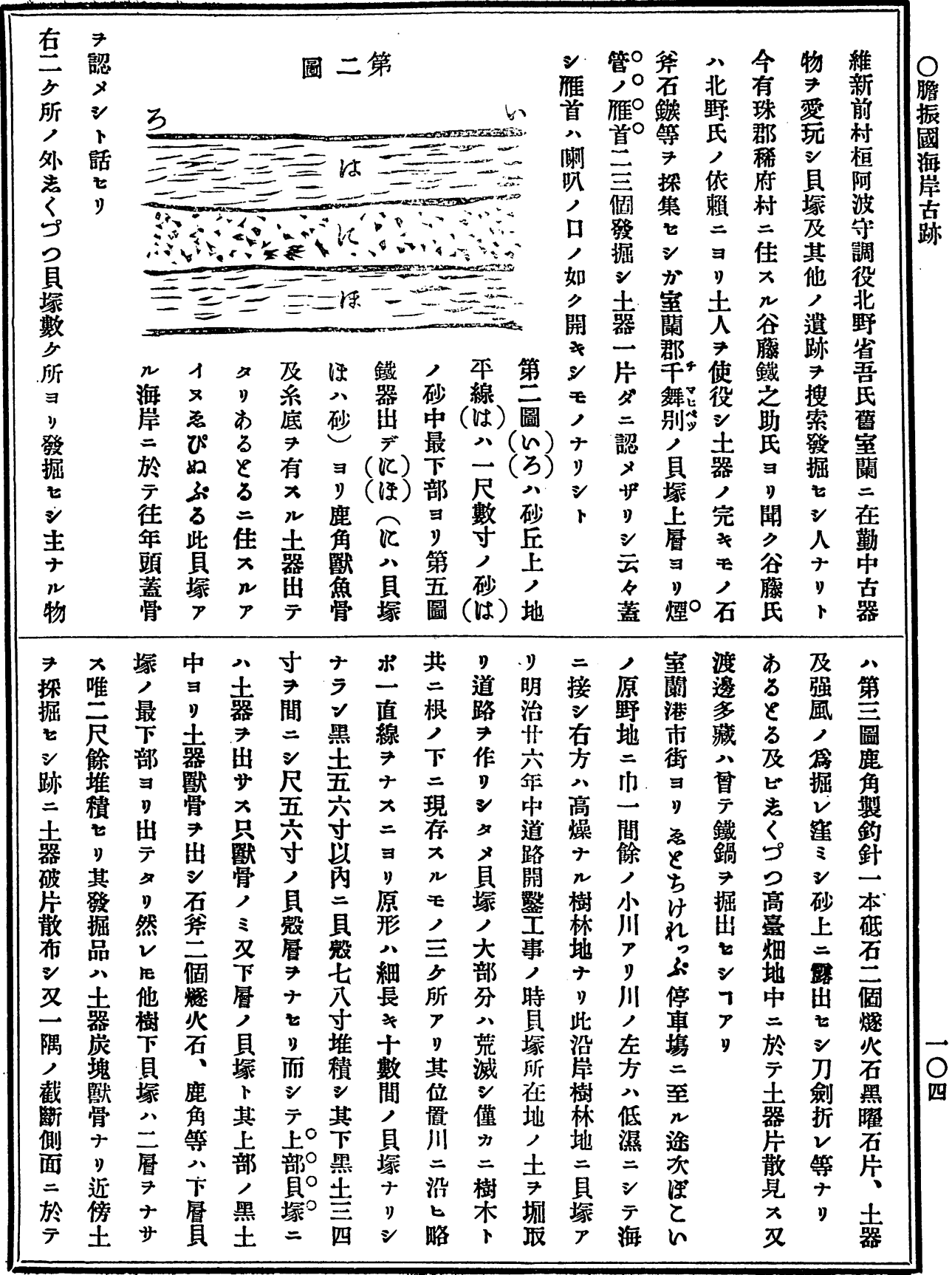




\section{月二十年八十二治明}

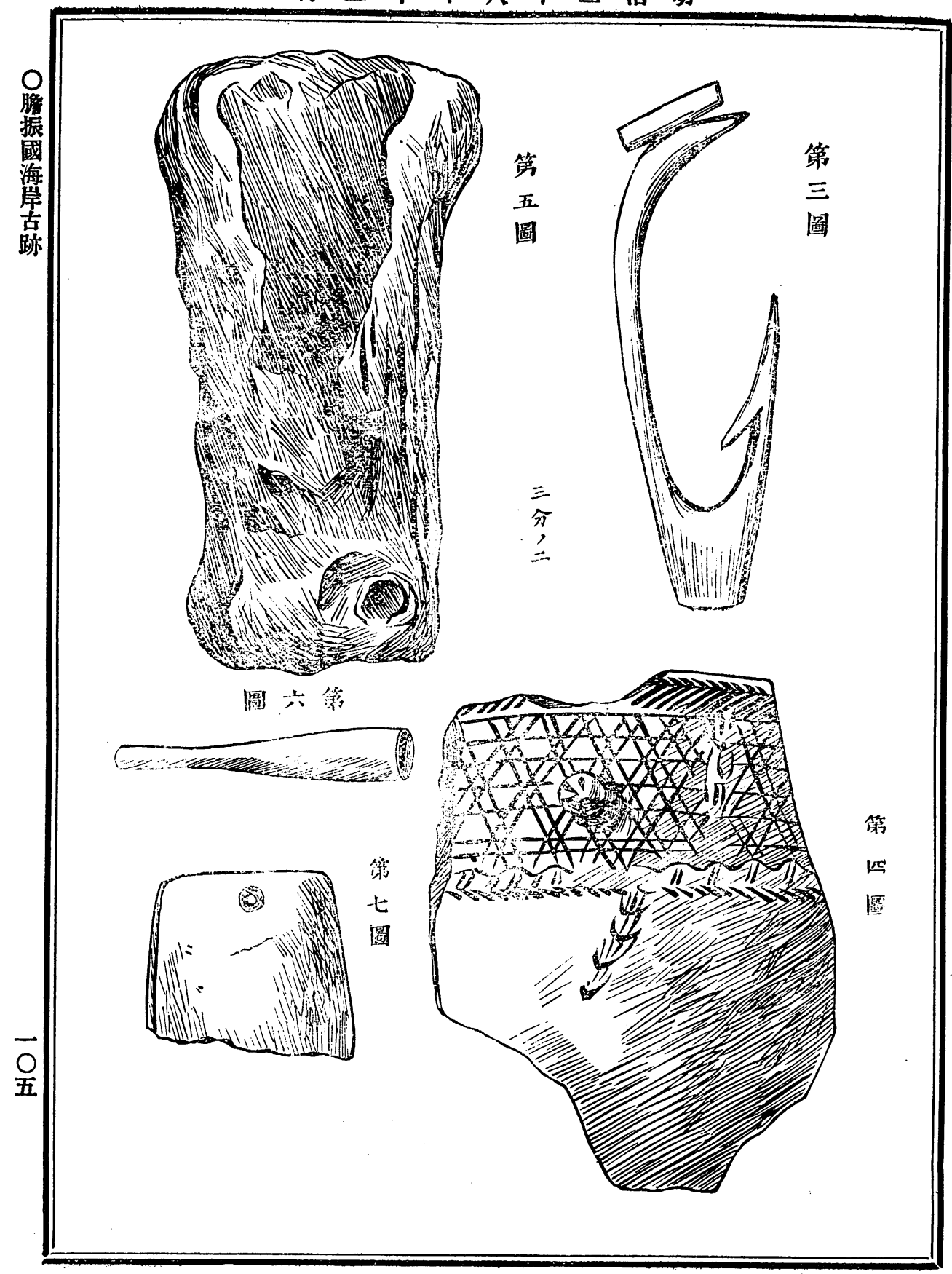


號七拾百第䟛稚會學類人京東

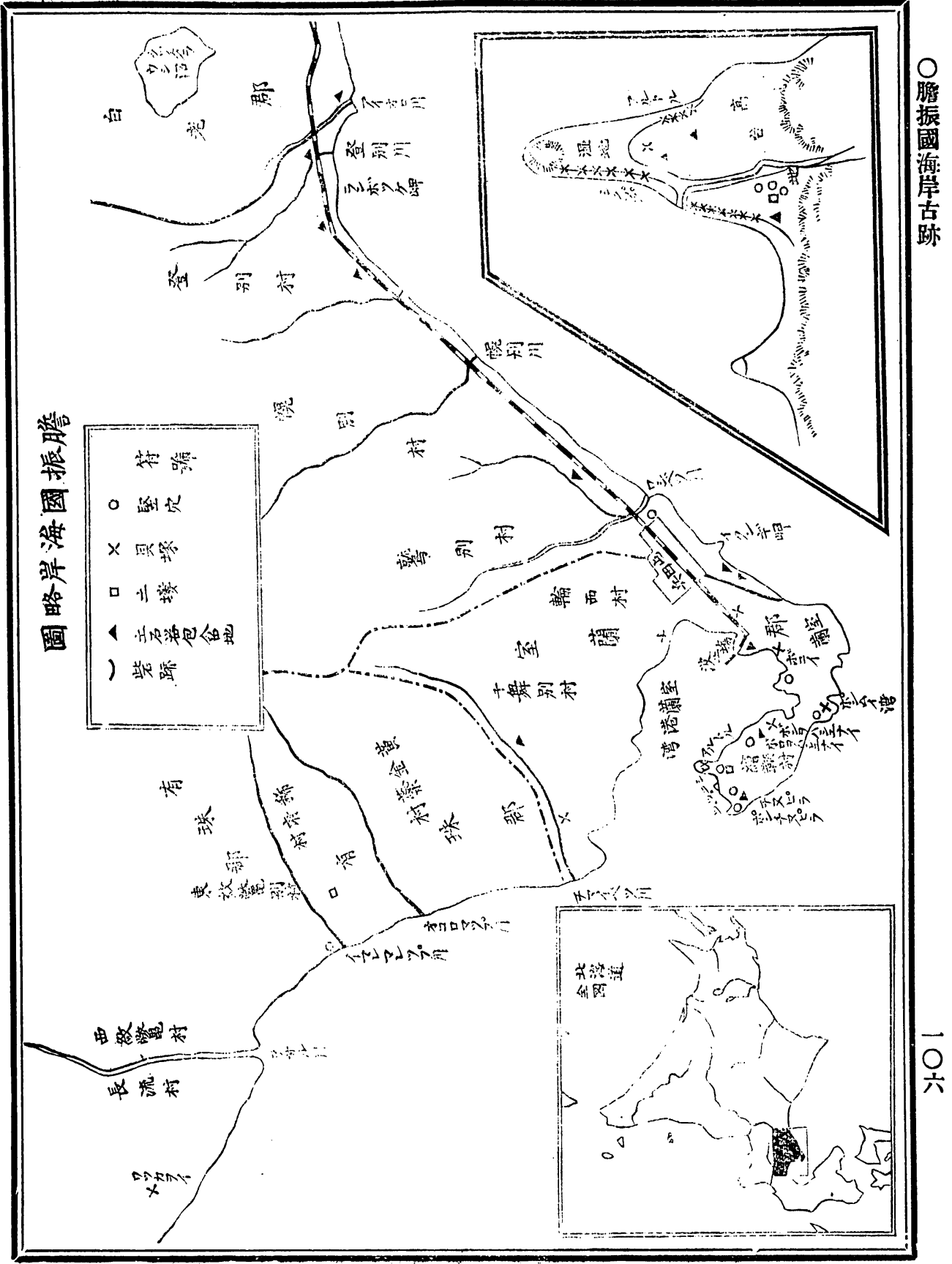




\section{月二十年八十三治明}

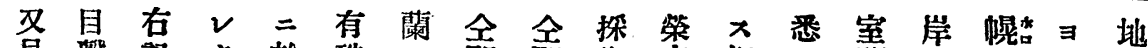

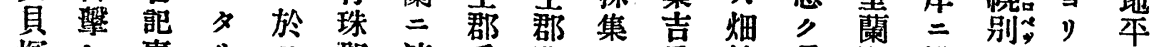
塚七事りテ郡渡据篦七氐地具郡堆郡探線

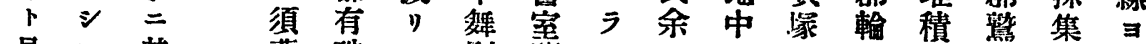

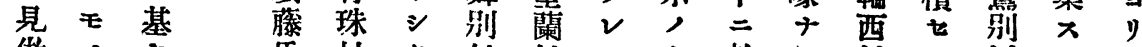

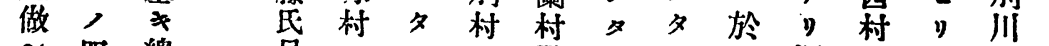

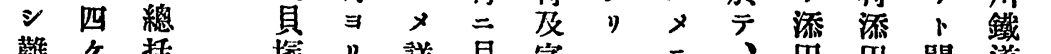

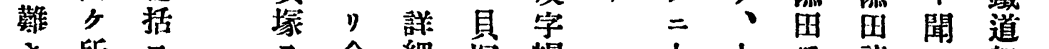

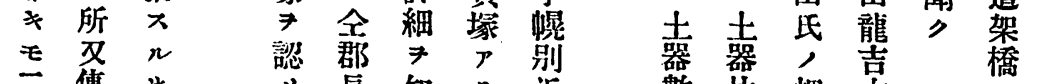
三傳 $\#$ 長 知 $y$ 近

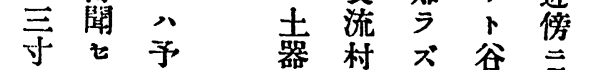
内 $シ$, 砋 各モ發石達微 具掘多 $九$ 等地

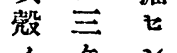
蓋 省 $上$ 堆所 モ 皘通, 乺 如字 七 棓四 $n+5$ E 一 所 万單 枝所

大 b

モ

器器, 吉橋 數片畑 术

十及 村

片官尔

黑 石 以 兵

曜 䆑 蓄

石一掘畑

燧下地

火探 ゲ 大

，集 8 凡

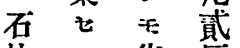

片》份度

及 後 上步

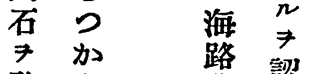

發を。蕗 認

獸 千 二,

骨須 達 地

月

牞

具骨骨 ル石時ア紋, 作右薄

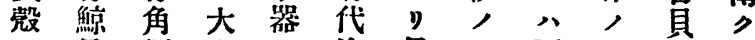

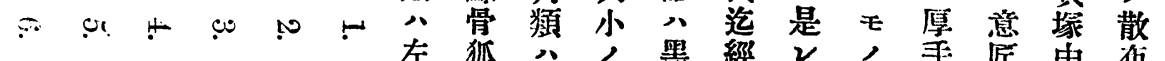

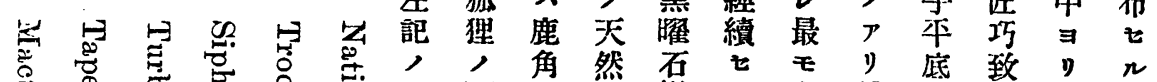
总 总

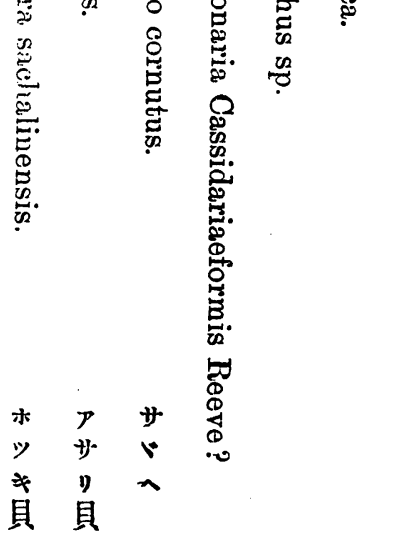
分学麇文 種三角り石令年化テテル公 ナ類製莽モ所上製溥士々 》 $ᄌ$ 魚遂, 7 部集手器所

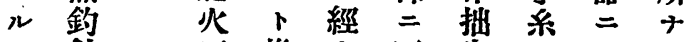
モ釬石推夕至委底 シ 》 , 碴 考 $n$ 多 等 テ 及カ石 明 * 輕 手繩 又当

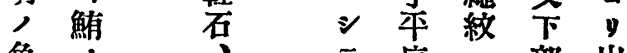
魚手 $テ$ 底 二 部出 兽凖人薄人 骨骨号乎ミテッれ 等系出稀出 †熊加底少レ少, y ヘ 製 $n=n$, 指导處無モ 製 


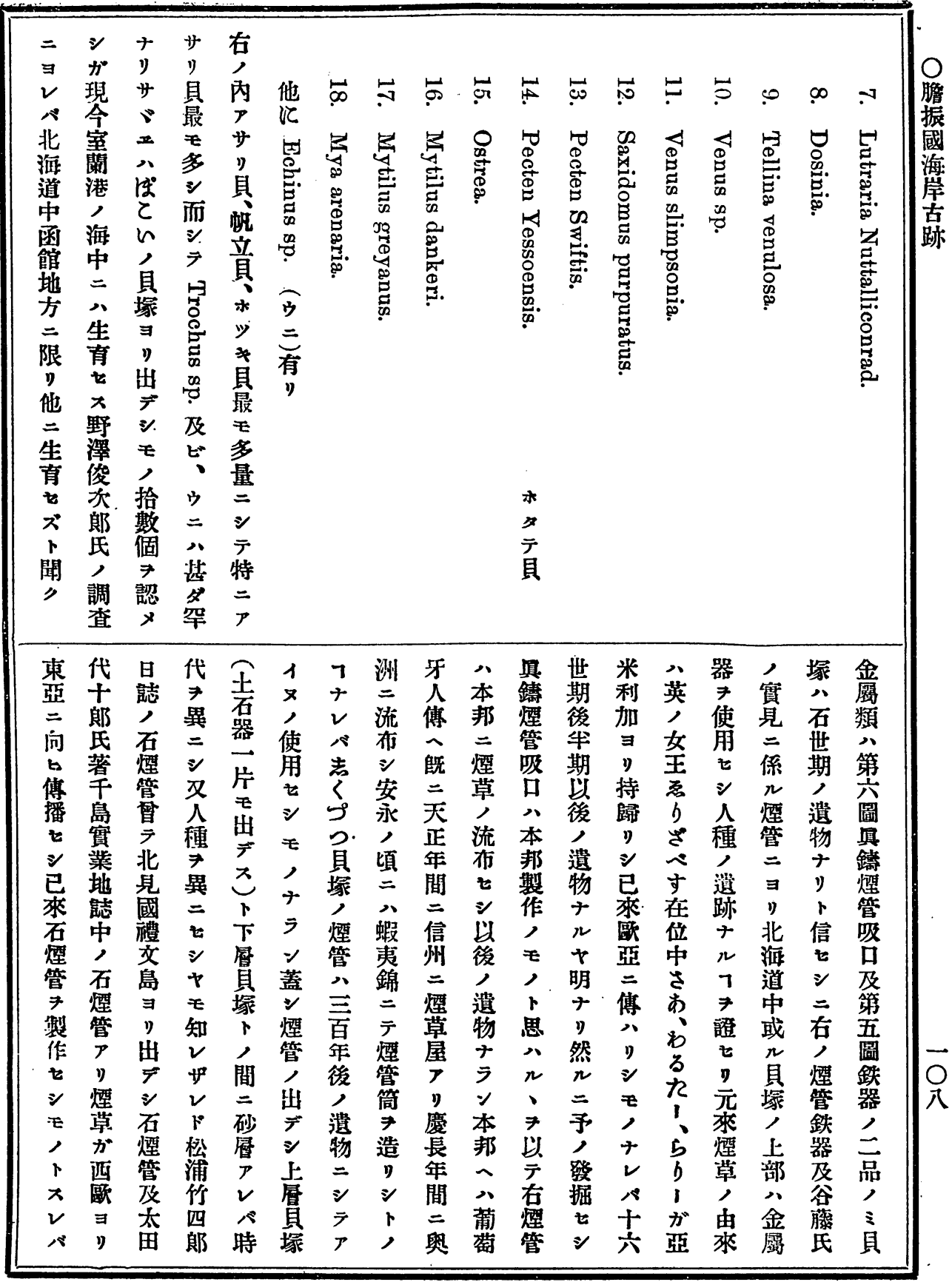




\section{月二十年八十二治 明}

○
膽
搙
國
海
崖
克
跡

别器市圆發籣

郡片 街形掘 港

䴙 $\Rightarrow$ 地, 入 柇

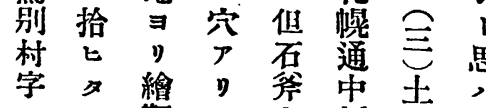

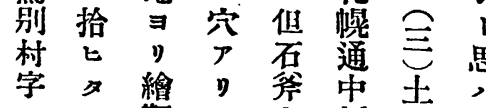

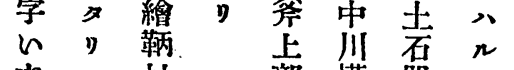

n 村

几 $\quad=$

至

梦途

義

溜

$=$

7
1
7

$\times$

漁

家

百

$>$
部 權 器

一藏 等

端 畑 包

地 含

中 $\exists$ 地

央

第

兩 七

㑡 堛

$\exists$ 石

y 突

所想折

$=$ 巧 -

於

咅

二 何

穿 全

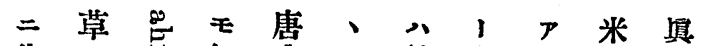

先 $\exists$ 知太蒲以

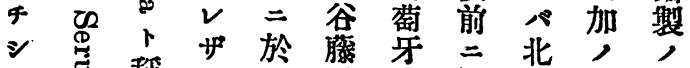

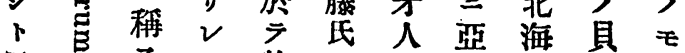

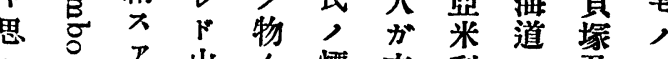

、1 1 出煙本利, 及

䊈 又开交管那加石其思

七八人換僱二ヨ煙他七

三古恓者首輸方管了合

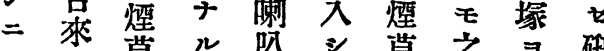

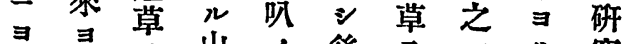

y 7 山, 後 7 开究

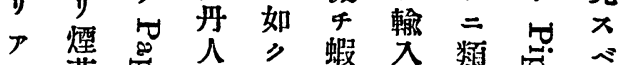

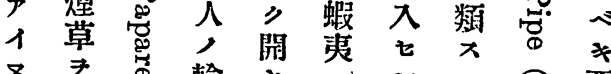

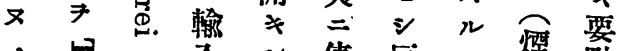

嵬苞卢入

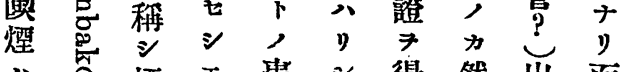

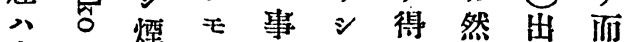

山ト管, 實卜 サ

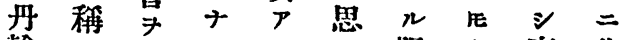

輸 シ 更ルン 八限与事北

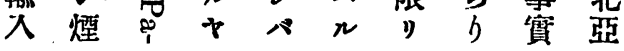

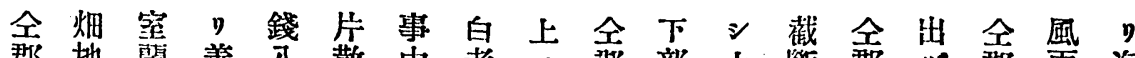

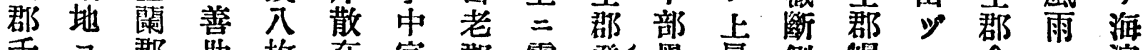

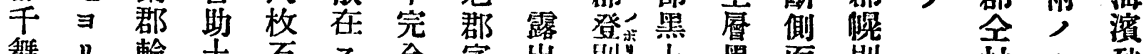

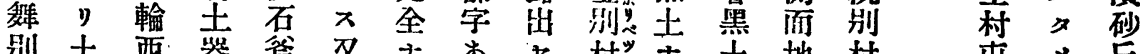

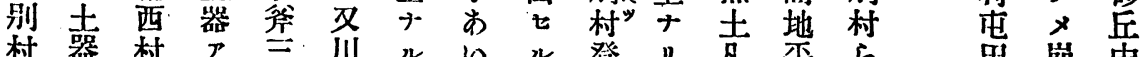

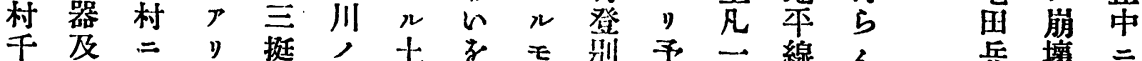

千及 $=$ 挺, 去をモ别予爷線儿兵壤

别甭於占掘左器

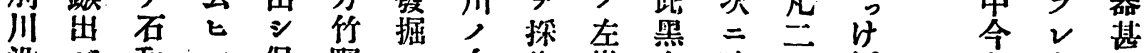

沿

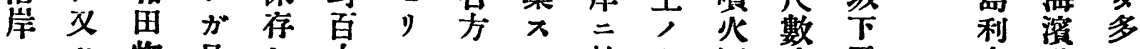

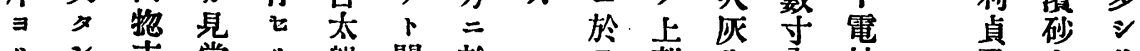

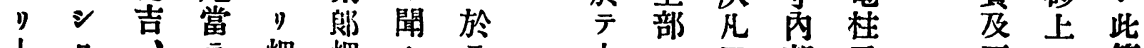

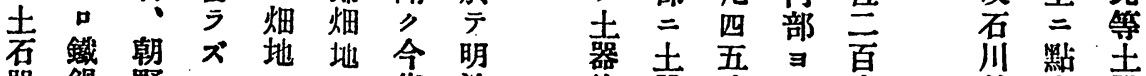

地地今 明

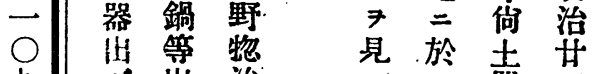

九

ル 㗊 五

》 添鯨葉芦遂鐵

》田骨善石道

龍鹿 勋 熹 開

吉

角忝曜䇾

片器寸リ兵某在 器

及片其士至,

石 7 下器三烟 包

唀認砂告號地モ含

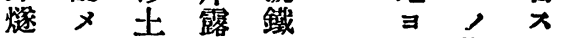

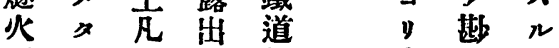

石り $\rightarrow$ 七 線

等展

土 砂

保石 I 砂此蓋,

喜 岳 
號七拾百第誌雜會學類人京東

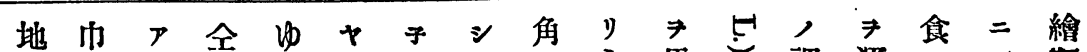
積深 $y$ 人。モ此が, 永黑三調運

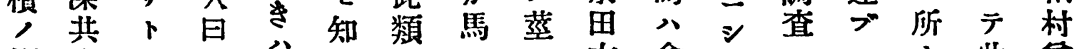
岬凡

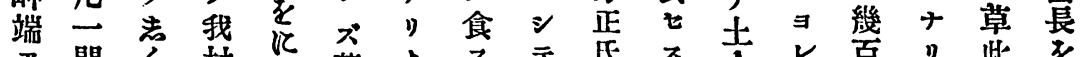

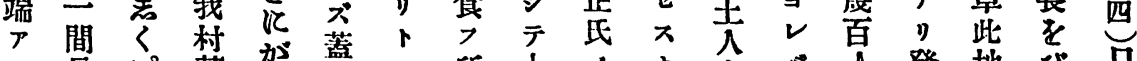

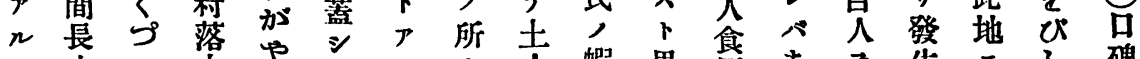

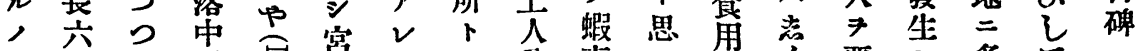

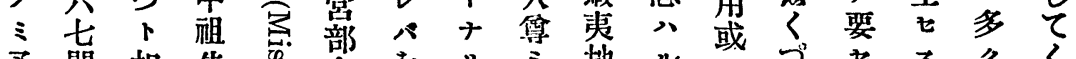

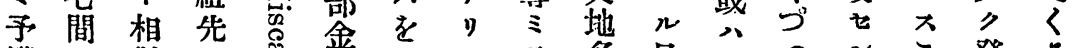

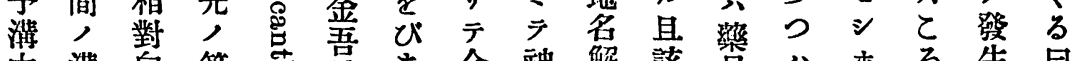

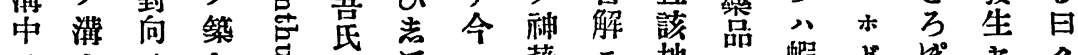

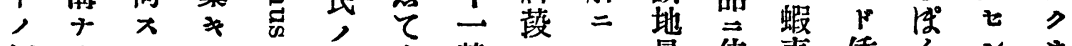
侧》ル

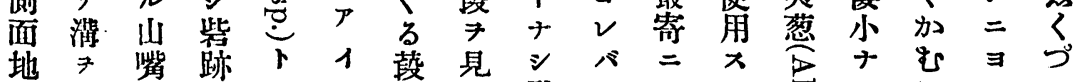

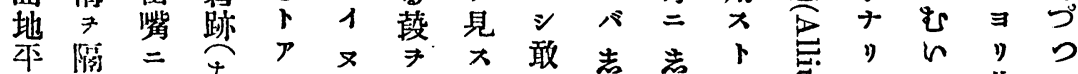

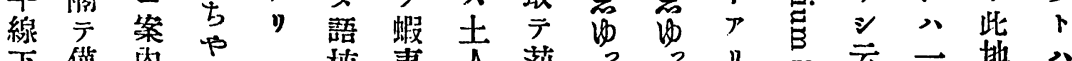

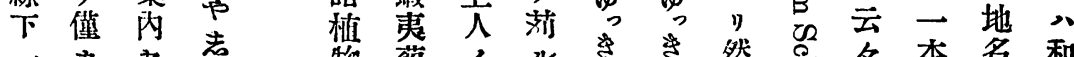

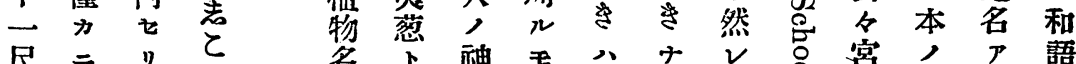

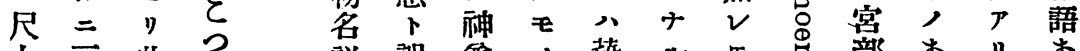

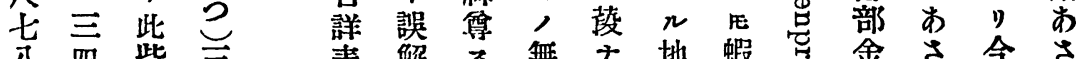

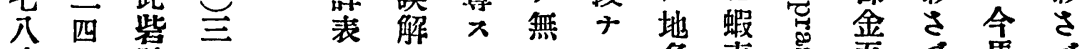
寸十跡々 二 以步

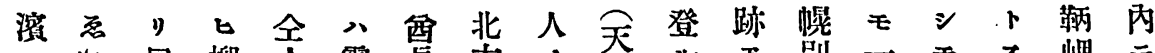

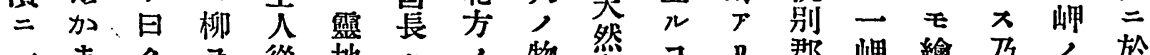

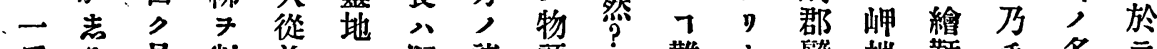

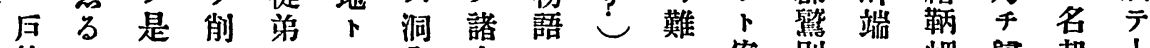
佳日 2 居

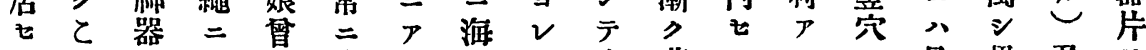
シろ = 作

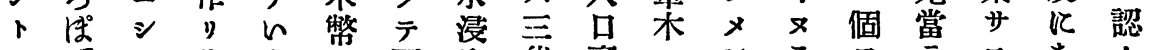

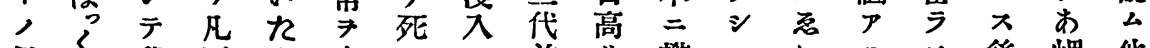

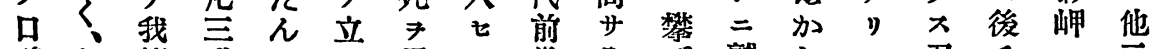

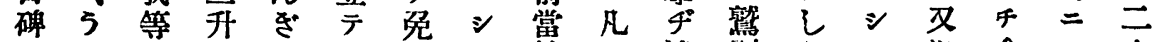

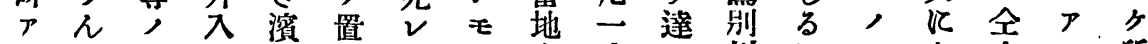
》ぐ䞇, 二 其る物土於 $⿻$ 紫二奥 $\pi=$ 岬不卜

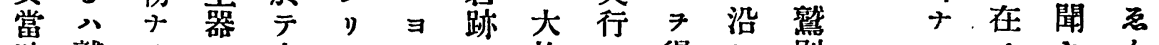

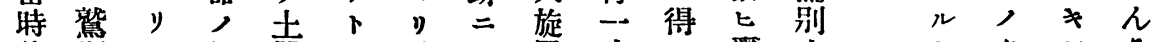

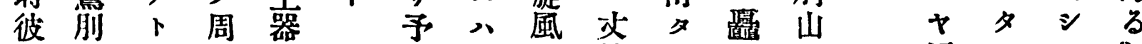

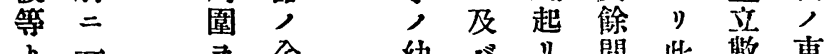

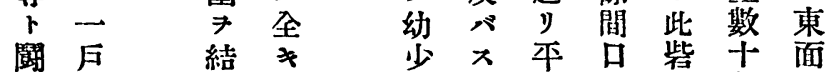

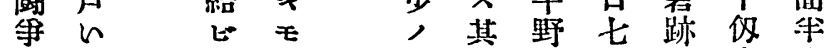

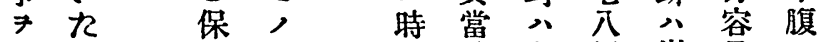
カ2 存 $\Rightarrow$ 特勿 尺岩易二 $\checkmark$ ほ 七拾 


\section{月三十年 $八+二$ 治 明}

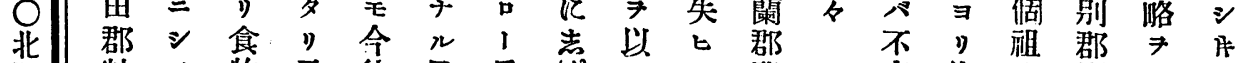

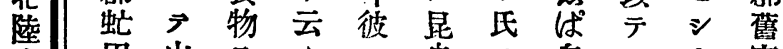
人 田山 7 公 2 虫, 鬼一室

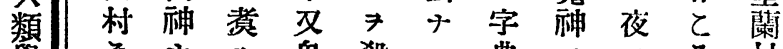
學总ナル鬼 殺ル典人, 万 村

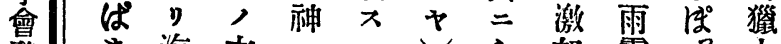
發

會

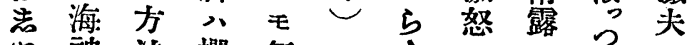
ぬ神 法櫻 何卜 ぷ 式日 $=7$ 及, 化古䚪防、中 の

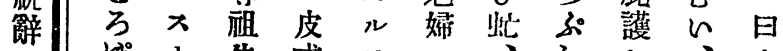

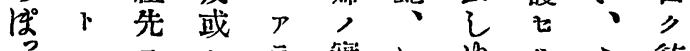

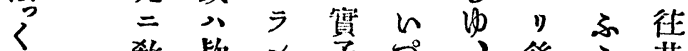

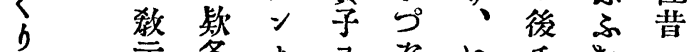
示冬17 尔的千专二

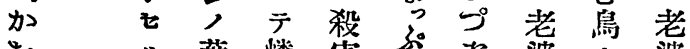

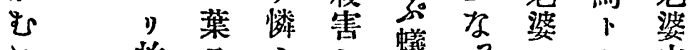

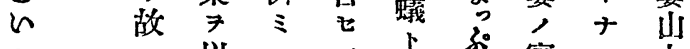

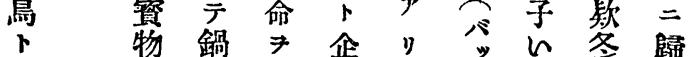
ナ 7 助 $テ$ 如千名, 路
吉 傅 先晎 $ァ$ 力 八 $⿻$ 别 1 は⿺ 兆》》村 $又$ 方 > $\approx$ 傅 $>=b$ 第が來 1 敎 神 \& 全, $>$ 則 河人嘪ど 千

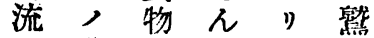
二父卜运云 投河 $三$ 朴と ス流 テ化 ろ ル二保石度

二流存製

如七

カリリ悡

大 其而

卜盖他挺

テ 江及

斯 䛇 器 燧

" テ - 火

七破 個 石

》壤、祖鏃
あ化を゙

るなる る染揹類

8 \& 8 碑 $V$ 地 學

- $の$ 供方の 一依、傅守江吾 時 b 何心性人 のてぞ き古令 話、限或 8 風 日 唡想 5 は $の$ 遗に 像公一少族必 止を、家なの要 り口偶のき考な てにな珍に融る ᄂ 言藏非を注 深、語品岕參、

一 $<$ 推

一 其 测 㱷

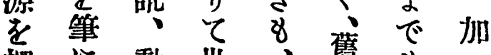

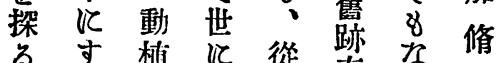

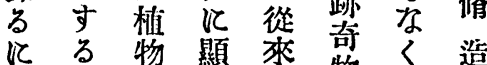
更沙徒物五追

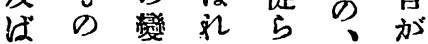

～佳物中》

ラ 北 テ 居 7 二豈

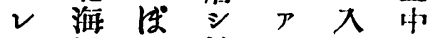
$\Rightarrow$ 道々 欵 1 》 》廳方冬 又身飛 此技

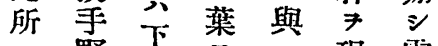
二野, 7 人現䁷 之澤龙 以及間 \% 俊義 テリ サ 二 深次 謝郎り根躰元》 长 7 來 動 造 小實 身 物りナ物躰 ノル人 名 リ二神 現 秒 盖 $\gamma=\cdots$ $\geqslant$ シ 調 こ 查了常 短 又 シ $\cong$ 小堅 補疑土十莫 助冬中心粘 七 $= \pm$ 器士 